\title{
Evaluation of Growth Performance, Blood Metabolites and Gene Expression Analysis in Egyptian Sheep Breeds, in Relation to Age
}

\author{
Gamal Ashour, Ahmed Gad, Ayat K. Fayed*, Neama A. Ashmawy and Ashraf El- Sayed \\ Department of Animal Production, Faculty of Agriculture, Cairo University, 12613 Giza, Egypt \\ *Corresponding's Email: ayat.kassem @agr.cu.edu.eg; (DoRCiD: 0000-0001-9846-9277
}

\begin{abstract}
The growth performance of lambs attributes to the economic viability of animals. Faster growth allows lambs to reach maturity at an early age. Therefore, the aim of this study was to compare growth performance, blood metabolites and expression of IGF-1, GH, and Leptin genes in three different Egyptian sheep breeds across age. Thirty Egyptian sheep males from three breeds (Ossimi, Rahmani and Barki) were divided into three ages categorize ( $7-9,10-12$, and $13-16$ months). The results showed that there was a significant increase in sheep's live body weights toward advanced ages till the second age category for all breeds, the highest values of linear body measurements were observed in Ossimi breed. There was a non-significant inverse effect of advanced age on blood glucose and total lipids levels in all sheep breeds. There wasn't any significant effect of interaction between age and breed on plasma total protein concentrations. According to age categories, Barki breed showed a significant upregulation of GH compared to the Ossimi breed in 7-9 months age category. However, Barki breed showed a significant down-regulation of IGF-1compared to the Ossimi breed in 7-9 months. Meanwhile, Leptin expression showed significant differences in Ossimi breed between 10-12 months age category and two other age categories. We concluded that measuring of physical body measurements, blood metabolites and GH, IGF-1 and Leptin genes in early ages is a good and accurate indicator for growth performance in Egyptian sheep breeds.
\end{abstract}

Key words: Blood metabolites, Egyptian breeds, Gene expression, Growth performance, Linear body measurements

\section{INTRODUCTION}

In Egypt, sheep breeding forms a great part of the agricultural economy, where animals are raised mostly in rural farmers. Egyptian sheep are important animal genetic resources, they are raised basically for mutton production, while wool and milk consider as secondary products (FAO, 2017). They are the third source of red meat in Egypt after cows and buffaloes, which considered the strategic stockpile of food security (EL-Hanafy and El-Saadani, 2009, El-Malky et al.2019).

Egyptian breeds are fat-tailed that characterized by extended breeding seasons, high fertility, and well adapted to harsh environmental conditions (Galal et al., 2005; EL-Hanafy and El-Saadani, 2009 Mahrous et al., 2016, Barakat et al., 2017; El-Malky et al., 2019).The total number of Egyptian sheep breeds is raised from 5,463,169 head in 2015 to $5,697,716$ head in 2017. Sheep provide 72,296 tons of meat, they contribute 6\% of the total red meat produced in Egypt and 99,322 tons of fresh milk (FAO, 2017). The growth rate of lambs is an important production trait and it reflects the economic viability of animals, which has a great role in a sheep production process. It is primarily influenced by a complex system such as genetics, immune responses, physiological status, and endocrine factors, in addition to other non-genetic factors (Grochowska et al., 2017, Singh et al., 2018; Veena et al., 2018).

There are many also non-genetic factors, such as nutrition, heat temperature and management system which controlling the phenotypic expression of the growth. Identification of such factors is important for adjustment to analyze genetic parameters and better planning for herd management (Dixit et al., 2011). Gene expression analysis allows to identifying genes that are responsible for the expression of interested economic traits. It is a very useful technique in early prediction and comparing animals with different economically important characteristics like growth traits (Dunn and Ryan, 2015). The growth hormone (GH), insulin-like growth factor-1 (IGF-1) and leptin genes are candidates for growth in ovine since they play a key role in growth regulation and development (Barzehkar et al. 2009, Nazari et al., 2016; Mahrous et al., 2016).

Measuring of gene expression and blood metabolites levels is a reliable method for evaluation sheep growth performance and health status in addition to it is a useful way for judging of individual animal physiological status, 
diagnosis of metabolic disorders, clinical nutritional balances, deficit condition, treatment monitoring and prognostics (Nath et al., 2014; Beigh et al., 2018). The mortality of pre- and post-weaning lambs, lower growth rates, and lack of feed are major problems facing most sheep farmers and they are main factors which have a negative effect on total productivity in sheep husbandry and represents an economic loss (Saleem et al., 2017; Elshazly and Youngs, 2019).

So, the aim of this study was to compare growth performance, blood metabolites and expression of IGF-1, GH, and Lepton genes in three different Egyptian sheep breeds across age.

\section{MATERIALS AND METHODS}

\section{Ethical approval}

The present work has been conducted in accordance with the guidelines of the ethical committee of Faculty of Agriculture - Cairo University. The experimental fieldwork was carried out in the Agriculture Experimental Station, Faculty of Agriculture- Cairo University. Whereas gene expression and blood metabolite analyses were executed at Cairo University Research Park, Faculty of Agriculture-Egypt.

\section{Experimental animals and diets}

Thirty Egyptian sheep males from (7 Ossimi, 8 Rahmani and 15 Barki) breeds were raised from age of 7 months till 16 months. The period of rearing was divided into three age categorize $(7-9,10-12$, and $13-16$ months). The average body weight of the experimental animals within each group was $(33.41 \pm 2.3,22.5 \pm 1.9$ and $24.9 \pm 4.9 \mathrm{~kg}$ respectively). Sheep were fed according to (NRC, 2002) and drinking water and mineral blocks was continuously available. All animals kept under the same managerial conditions.

\section{Growth traits measurements}

Physical measurements including body weight, body length, hip height, and heart girth were measured monthly during this study. Body length was considered as the distance between the point of shoulder and pin bone (Afolayan et al., 2006). Heart girth was the circumference measurement taken behind the fore legs (Ibrahim, 2015). Hip height was measured from hips up to the end of hoof. It is a vertical distance from the highest point of the hips to the ground surface at the level of the rear legs (Afolayan et al., 2006).

\section{Blood sampling}

Blood samples were collected monthly from each individual animal in the morning before feeding. Ten ml of blood were collected from the jugular vein in a heparinized $(15 \mathrm{ml})$ tube. Eight $\mathrm{ml}$ from each sample were used for biochemical assays and two $\mathrm{ml}$ were used for gene expression analysis. For biochemical assays, blood samples were centrifuged at $3000 \mathrm{rpm}$ for $20 \mathrm{~min}$, the supernatant of clear plasma was aspirated and placed into capped Eppendorf tubes and stored at $-20^{\circ} \mathrm{C}$ till use.

\section{Biochemical assays}

Glucose concentration (mg/dl) was measured colorimetrically using Glucose kit (Bio-Diagnostic Dokki, Giza, Egypt) as described by Trinder (1969). Total protein content (g/dl) was determined by using Protein Biuret Kit (BioDiagnostic Dokki, Giza, Egypt) as mentioned by Gornal et al. (1949) and total lipids (mg/dl) were analyzed using Total Lipids Kit (Bio-Diagnostic Dokki, Giza, Egypt) according to Zollner and Kirsch (1962). Colorimetric analysis for all biochemical assays has been done using STAT LAB SZSL0148 (ver 5.5 SPECTRUM).

\section{Gene expression analysis}

\section{RNA isolation and cDNA synthesis}

Total RNA was isolated from blood samples using QiaAamp RNA blood mini isolation kit (Qiagen, Clinilab, Cairo, Egypt) according to the manufacturer's instructions. Briefly, one ml of whole blood was mixed with five ml extraction buffer, incubated on ice for $10 \mathrm{~min}$ and briefly mixing by vortexing two times during incubation. Leukocytes pellet was obtained after centrifugation at $400 \mathrm{xg}$ for $10 \mathrm{~min}$ at $4{ }^{\circ} \mathrm{C}$. The collected pellet was suspended in $2 \mathrm{ml}$ extraction buffer followed by vortexing and centrifugation at $400 \mathrm{xg}$ for $10 \mathrm{~min}$ at $4{ }^{\circ} \mathrm{C}$. Afterward, washing buffer 600 ul was added and mixed by vortexing. The extract was loaded onto a purification column and centrifuged to allow for the RNA to bind to the spin column. The column was washed twice with washing buffer and finally eluted with $30 \mu 1$ RNase free water. For each sample, cDNA synthesis has been performed using oligo (dT) 23 primer, random primer and superscript reverse transcriptase II (Thermo Scientific, Sigma Scientific Services, Giza, Egypt). One $\mu 1$ of oligo (dT) 23 primer and one $\mu 1$ random primer were added to $10 \mu \mathrm{l}$ RA sample and the mixture was incubated for 3 min at $70^{\circ} \mathrm{C}$ and then immediately chilled on ice. Eight microlitre of the master mix containing $4 \mu \mathrm{l}$ of $5 \mathrm{x}$ first strand buffer, $2 \mu 1$ of $0.1 \mathrm{M}$ DTT, $1 \mu \mathrm{l}$ of dNTP $(10 \mathrm{pmol} / \mu \mathrm{l})$ and $0.3 \mu \mathrm{l}$ of RNase inhibitor and $0.7 \mu \mathrm{l}$ of Super Script IITM reverse transcriptase (200 
unit/ $\mu \mathrm{l}$ ) was added to the mixture and incubated for $90 \mathrm{~min}$ at $42^{\circ} \mathrm{C}$ followed by heat inactivation for $15 \mathrm{~min}$ at $70^{\circ} \mathrm{C}$. The synthesized cDNA was stored at $-20^{\circ} \mathrm{C}$ for further use.

\section{Quantitative real-time PCR analysis}

Primers were designed using Primer3 software (Table 1). Quantitative analyses of cDNA samples were performed on Step One Plus ${ }^{\mathrm{TM}}$ instrument (Applied Biosystems). Independent qRT-PCR (4 animals each age group) was performed in a $20 \mu \mathrm{l}$ reaction volume containing Maxima SYBR Green/ROX qPCR Master Mix (Thermo Scientific, Sigma Scientific Services, Giza, Egypt), the cDNA samples and the specific forward and reverse primers. The thermal cycling parameters were set at $95^{\circ} \mathrm{C}$ for $3 \mathrm{~min}$., 40 cycles of $95^{\circ} \mathrm{C}$ for $15 \mathrm{sec}$. and $60^{\circ} \mathrm{C}$ for $1 \mathrm{~min}$. After the end of the last cycle, a dissociation curve was generated by starting the fluorescence acquisition at $60^{\circ} \mathrm{C}$ and taking measurements every 7 second interval until the temperature reached $95^{\circ} \mathrm{C}$. The comparative cycle threshold (CT) method was used to quantify expression levels as previously described (Liu, 2007). Expressions of three different transcripts (G.H, IGF-1, and Leptin) were analyzed using real-time PCR and fold changes were calculated using $\Delta \Delta \mathrm{Ct}$ method according to Kelly et al. (2012) Lamas et al. (2018) and Samara et al. (2008).

Table 1. Details of primers used for quantitative real-time PCR.

\begin{tabular}{|c|c|c|c|c|}
\hline $\begin{array}{l}\text { Gene } \\
\text { sympol }\end{array}$ & $\begin{array}{c}\text { Gene bank } \\
\text { accession } \\
\text { number }\end{array}$ & Primer sequences & $\begin{array}{c}\text { Annealing } \\
\text { temperature } \\
\left({ }^{\circ} \mathrm{C}\right) \\
\end{array}$ & Reference \\
\hline GH sheep & (NM_001009315) & $\begin{array}{l}\text { F: 5'- GGCCCAGCAGAAATCAGACT -3' } \\
\text { R: 5'-CTTGAGCAGCGCATCATCAC -3 }\end{array}$ & 55 & (Jia et al., 2014) \\
\hline IGF-1 & (NM_001009774.3) & $\begin{array}{l}\text { F: 5'-TCGCATCTCTTCTATCTGGCCCTGT -3' } \\
\text { R: 5'- GCAGTACATCTCCAGCCTCCTCAGA -3 }\end{array}$ & 55 & (Rotwein, 2017) \\
\hline Leptin & (XM_027968780.1) & $\begin{array}{l}\text { F: 5'- GCCTATGTGGGCATCCTTTA -3' } \\
\text { R: 5'- TGGAACAGGGAGGAAGACTG -3 }\end{array}$ & 55 & (Shojaei, et al., 2011) \\
\hline GAPDH & (NM_001190390.1) & $\begin{array}{l}\text { F: 5'-ATCAAGTGGGGTGATGCTGG -3' } \\
\text { R: 5'- GGCGTGGACAGTGGTCATAA -3' }\end{array}$ & 55 & (Vorachek et al., 2013) \\
\hline
\end{tabular}

\section{Statistical analysis}

Statistical analysis of data was carried out applying SAS package (2008). All values were expressed means and standard errors (SE). The significance was measured according to Duncan Multiple Range test (1995). The statistical model was used as following: $Y_{i j k}=\mu+B_{i}+G_{j}+(B * G)_{i j}+e_{i j k}$

Where, $\mathrm{Y}$ is the dependent variable under study, $\mu$ is the overall mean, $\mathrm{B}$ and $\mathrm{G}$ indicate the fixed effect of breed and age category, respectively. $\mathrm{B} * \mathrm{G}$ indicates the interaction between breed and age category and e is the random error assumed N. I. D. $(0, \delta 2)$. The mRNA transcriptional quantity was indicated as the average \pm standard error. A histogram of DCt was used to verify the conclusion that the value of DCt had a negative relationship with transcriptional quantity. The relative gene expression level was analyzed using $2^{-\Delta \Delta \mathrm{Ct}}$ method which has been described by Liu (2007). The mean values were compared for statistical significance using Duncan's range test (Duncan, 1955). Differences were considered statistically significant at $\mathrm{P} \leq 0.05$.

\section{RESULTS}

\section{Growth traits}

Live body weight

Data on the effect of different age categories first category (7-9 months), second category (10-12 months) and third category from (13-16 months) and sheep breeds (Ossimi, Rahmani, and Barki) on physical body measurements were calculated as (mean $\pm \mathrm{SE}$ ) in table 2. The results of this study indicated that there was a significant increase in sheep's live body weights toward advanced ages till the second age category for all breeds, followed by non-significant increasing at the third category. Meanwhile, there was a significant effect of breed between Ossimi breed and two other breeds, where live body weight for Ossimi breed was bigger $(45.25 \pm 1.98 \mathrm{Kg})$ than two other breeds $(43.89 \pm 1.17$ for Rahmani and $44.11 \pm 1.68$ for Barki), and there weren't any significant differences in live body weight between Rahmani and Barki breeds at three age categories. Meanwhile, there was significant effect of interaction between age and breed on live body weight $(\mathrm{P}<0.05)$.

\section{Body length}

The observed measures of sheep's body length showed that there was a non-significant positive trend of body length in Ossimi breed with all age categories. Furthermore, Barki and Rahmani breeds had a non-significant (somewhat positive) effect of advanced age categories. Ossimi breed had a greater value of body length $(97.93 \pm 4.08 \mathrm{~cm})$ followed 
by Rahmani breed $(95.43 \pm 1.58 \mathrm{~cm})$, while Barki breed had the lowest value of body length $(91.50 \pm 3.57 \mathrm{~cm})$. Present results indicated that there wasn't any effect of sheep breed on sheep's body length at all age categories. Moreover, the effect of interaction between sheep age and breed was insignificant.

\section{Hip (rump) height}

The results of sheep's hip height, indicated that there was a positive significant effect of age and breed between Ossimi and Rahmani sheep till the second age category, while at the third age categories no significant differences of age and breed $(\mathrm{P}<0.05)$ were found between all sheep breeds. The highest value of hip height was observed in Ossimi breed followed by Barki breed and the lowest ones were measured in Rahmani. In addition to there wasn't any significant effect of interaction between age categories and breed on animal's hip height.

\section{Heart girth}

Heart girth positively increased according to age categories for all sheep breeds. It was found that Ossimi breed significantly affected $(\mathrm{P}<0.05)$ the values of heart girth comparing to two other breeds at first age category, while at second age category there was a significant difference between Ossimi sheep and Rahmani and at the third category there was significant difference between Ossimi and Barki. The largest value of heart girth was observed in Ossimi breed $(85.25 \pm 0.95 \mathrm{~cm})$, whereas there wasn't any clear effect of breed between Rahmani and Barki breed at all age categories. However Rahmani breed has a greater value of heart girth $(79.93 \pm 1.70 \mathrm{~cm})$ comparing to Barki breed $(77.86 \pm 2.02$ $\mathrm{cm})$. Furthermore, no significant effect of the interaction between age categories and breed was observed on sheep's heart girth.

Table 2. Physical body measurements (mean \pm SE) in Egyptian sheep breeds and age categories

\begin{tabular}{lccccc}
\hline Breed & Age (month) & Live body weight $(\mathbf{K g})$ & Length $(\mathbf{c m})$ & Hip height $(\mathbf{c m})$ & Heart girth $(\mathbf{c m})$ \\
\hline \multirow{3}{*}{ Ossimi } & $7-9$ & $33.42 \pm 0.97^{\mathrm{b}, \mathrm{A}}$ & $93.50 \pm 2.97$ & $69.83 \pm 1.11^{\mathrm{a}, \mathrm{A}}$ & $77.83 \pm 1.87^{\mathrm{b}, \mathrm{A}}$ \\
& $10-12$ & $44.93 \pm 1.82^{\mathrm{a}, \mathrm{A}}$ & $97.57 \pm 3.40$ & $71.43 \pm 2.36^{\mathrm{a}, \mathrm{A}}$ & $82.29 \pm 1.49^{\mathrm{ab}, \mathrm{A}}$ \\
& $13-16$ & $45.25 \pm 1.98^{\mathrm{a}}$ & $97.93 \pm 4.08$ & $71.25 \pm 1.11^{\mathrm{a}}$ & $85.25 \pm 0.95^{\mathrm{a}, \mathrm{A}}$ \\
\hline \multirow{3}{*}{ Rahmani } & $7-9$ & $22.50 \pm 0.96^{\mathrm{c}, \mathrm{B}}$ & $93.50 \pm 0.50$ & $61.75 \pm 2.25^{\mathrm{b}, \mathrm{B}}$ & $66.00 \pm 1.92^{\mathrm{b}, \mathrm{B}}$ \\
& $10-12$ & $33.38 \pm 0.95^{\mathrm{b}, \mathrm{B}}$ & $91.42 \pm 3.55$ & $64.67 \pm 0.92^{\mathrm{b}, \mathrm{B}}$ & $72.92 \pm 2.88^{\mathrm{ab}, \mathrm{B}}$ \\
& $13-16$ & $43.89 \pm 1.17^{\mathrm{a}}$ & $95.43 \pm 1.58$ & $69.36 \pm 1.01^{\mathrm{a}}$ & $79.93 \pm 1.70^{\mathrm{a}, \mathrm{AB}}$ \\
\hline \multirow{3}{*}{ Barki } & $7-9$ & $24.90 \pm 1.48^{\mathrm{c}, \mathrm{B}}$ & $87.60 \pm 4.38$ & $62.00 \pm 1.38^{\mathrm{b}, \mathrm{B}}$ & $64.90 \pm 1.28^{\mathrm{b}, \mathrm{B}}$ \\
& $10-12$ & $35.90 \pm 1.30^{\mathrm{b}, \mathrm{B}}$ & $93.83 \pm 2.74$ & $69.06 \pm 1.15^{\mathrm{a}, \mathrm{A}}$ & $75.33 \pm 2.21^{\mathrm{a}, \mathrm{AB}}$ \\
& $13-16$ & $44.11 \pm 1.68^{\mathrm{a}}$ & $91.50 \pm 3.578$ & $70.07 \pm 1.39^{\mathrm{a}}$ & $77.86 \pm 2.02^{\mathrm{a}, \mathrm{B}}$ \\
\hline
\end{tabular}

$\overline{\mathrm{a}, \mathrm{b}, \mathrm{c}}$ Significant differences $(\mathrm{P}<0.05)$ between age categories among each breed. ${ }^{\mathrm{A}, \mathrm{B}, \mathrm{C}}$ Significant differences $(\mathrm{P}<0.05)$ between breeds at each age category.

\section{Blood metabolites \\ Glucose}

The values of the blood parameters in relation to sheep age categories and breeds are presented in table 3 . The results of the current study showed that there was a non-significant inverse effect of advance age and blood glucose levels in all sheep breeds. In addition to there wasn't any clear effect of sheep breed on plasma glucose concentrations. The highest values were measured in Barki breed $(60.63 \pm 2.74 \mathrm{mg} / \mathrm{dl})$ and the lowest one was reviewed in Rahmani breed $(50.90 \pm 3.94 \mathrm{mg} / \mathrm{dl})$. Meanwhile, there wasn't any significant effect of interaction between age and breed on plasma glucose concentrations.

\section{Total protein}

The presented data in table 3 for Ossimi, Rahmani and Barki breeds during the period from (7- 9), (10- 12) and (1316) months respectively showed that there were a significant inverse differences on plasma total protein between the first and third age categories for Ossimi breed, and in Rahmani breed, there were significant inverse differences between first age category and to other categories, while in Barki breed there weren't any significant differences between all age categories. The current results concluded that there weren't any significant differences on plasma total protein concentrations during the first and third age categories for all sheep breed. While during the period from 10-12 months there was a significant effect of breed between Ossimi and Rahmani. According to present results, Rahmani breed had a greater value $(7.48 \pm 0.28 \mathrm{~g} / \mathrm{dl})$ of total protein compared to two other breeds. Meanwhile, there wasn't any significant effect of interaction between age and breed on plasma total protein concentrations.

\section{Total lipids}

The results of this study showed that there was a non-significant negative trend of advanced age on total lipids levels in Ossimi sheep, whereas in Rahmani breed there was no clear effect of age on blood total lipids concentrations, while Barki breed showed a non-significant positive effect of age on blood total lipids concentrations. The results of this study showed that there wasn't any significant effect of sheep breed on plasma total lipids. Meanwhile, there was a significant effect of interaction between age and breed on total lipids $(\mathrm{P}=0.0021)$. 
Table 3. Blood metabolites (mean \pm SE) in Egyptian sheep breeds and age categories

\begin{tabular}{lcccc}
\hline Breed & Age (month) & Glucose $(\mathbf{m g} / \mathbf{d l})$ & Total Protein $(\mathbf{g} / \mathbf{d l})$ & Total Lipids $(\mathbf{m g} / \mathbf{d l})$ \\
\hline \multirow{3}{*}{ Ossimi } & $7-9$ & $57.43 \pm 6.94$ & $7.19 \pm 0.50^{\mathrm{a}}$ & $822.94 \pm 24.40$ \\
& $10-12$ & $55.65 \pm 8.47$ & $7.01 \pm 0.27^{\mathrm{ab}, \mathrm{A}}$ & $820.61 \pm 18.37$ \\
& $13-16$ & $50.97 \pm 7.41$ & $5.88 \pm 0.23^{\mathrm{b}, \mathrm{B}}$ & $763.04 \pm 21.02$ \\
\hline \multirow{2}{*}{ Rahmani } & $7-9$ & $50.90 \pm 3.94$ & $7.48 \pm 0.28^{\mathrm{a}}$ & $771.63 \pm 9.41$ \\
& $10-12$ & $55.67 \pm 4.48$ & $6.18 \pm 0.20^{\mathrm{b}, \mathrm{B}}$ & $844.89 \pm 31.77$ \\
\hline \multirow{3}{*}{ Barki } & $13-16$ & $54.75 \pm 3.77$ & $6.58 \pm 0.21^{\mathrm{b}, \mathrm{AB}}$ & $807.07 \pm 14.87$ \\
& $7-9$ & $58.03 \pm 3.00$ & $6.73 \pm 0.31^{\mathrm{a}}$ & $806.36 \pm 16.10$ \\
\hline
\end{tabular}

$\overline{\mathrm{a}, \mathrm{b}, \mathrm{c}}$ Different letters indicate significant differences $(\mathrm{P}<0.05)$ between ages at each breed. ${ }^{\mathrm{A}, \mathrm{B}, \mathrm{C}}$ Different letters indicate significant differences $(\mathrm{P}<0.05)$ between breeds at each age category.

\section{Gene expression analysis}

\section{Growth hormone $(\mathrm{GH})$ gene}

Among the age categories, the Barki breed showed a significant up-regulation of GHcompared to the Ossimi breed in the 7-9 months age category. Rahmani breed showed a significant up-regulation of GHcompared to the Ossimi breed in the 13-16 months age category. However, there were no significant differences between all sheep breeds in the analyzed age category (10-12 months) (Figure 1A). Among each breed, the Ossimi breed showed a significant downregulation of GH expression level in the age category 13-16 months compared to the other ages. However, Rahmani and Barki breeds showed no significant differences across the different analysed age categories (Figure 2B).

\section{Insulin-like growth factor-1 (IGF-1) gene}

Among the age categories, the Barki breed showed a significant down-regulation of IGF-1compared to the Ossimi breed in the 7-9 months age category and Ossimi and Rahmani breeds in the 10-12 months age category. However, there were no significant differences between Ossimi and Rahmani breeds in the two analysed age categories (10-12 and 13-16 months) (Figure 2A). Among each breed, there were no significant differences in IGF-1 expression levels across the different age categories. However, Ossimi and Rahmani breeds tend to have a pattern of higher expression level in the age category 10-12 months but Barki breed tends to have lower expression in the 10-12 age category compared to 7-9 months age category (Figure 2B).

\section{Leptin gene}

Among the age categories, the Barki breed showed a significant up-regulation of leptincompared to the Ossimi breed in the 7-9 months age category, while Rahmani breed showed a significant down-regulation in the 10-12 months age category compared to Ossimi and Barki breeds. At the 13-16 months age category, Rahmani breed showed a significant up-regulation of leptincompared to the Ossimi breed (Figure 3A). Ossimi breed showed a significant downregulation of Leptinexpression level in the age categories 7-9 and 13-16 months compared to the 10-12 months age category. The other two breeds didn't show any significant differences among the analysed age categories (Figure 3B).
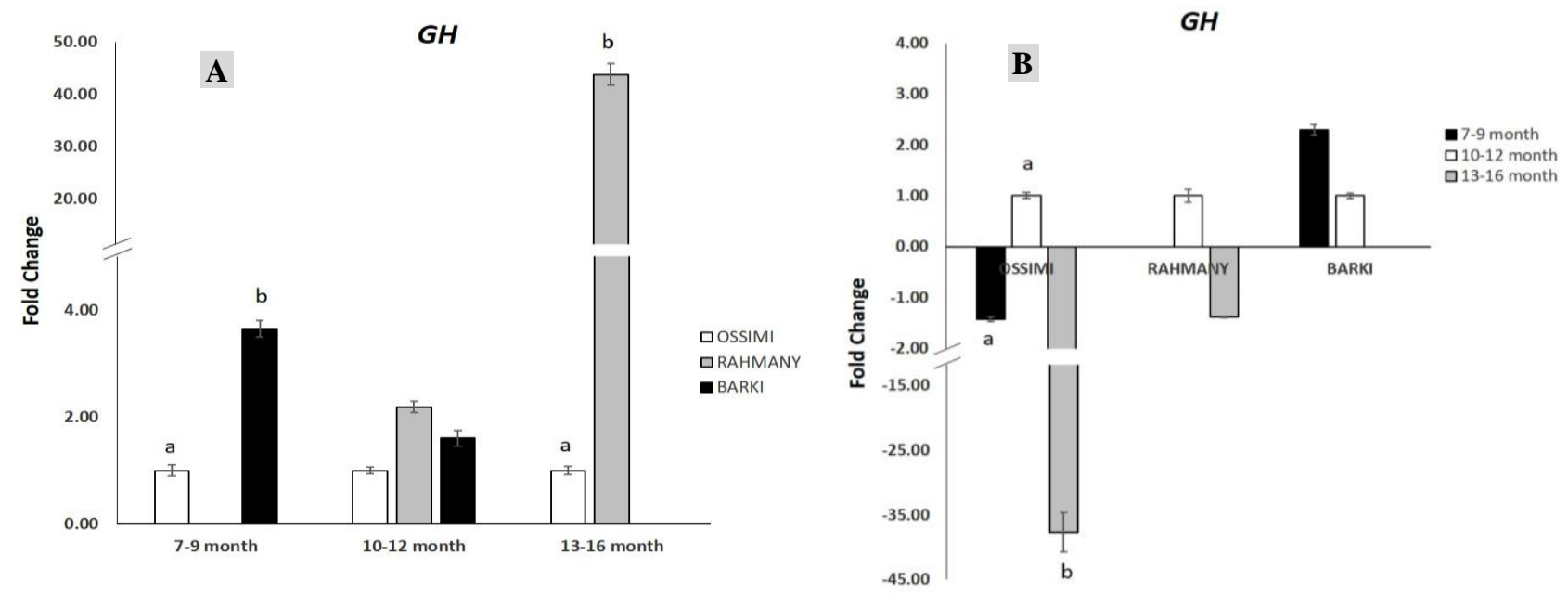

Figure 1. Expression differences in $G H$ between Egyptian sheep breeds (A) or age categories among each breed (B). ${ }^{\text {a,b,c }}$ Different letters indicate significant differences $(\mathrm{P}<0.05)$. 

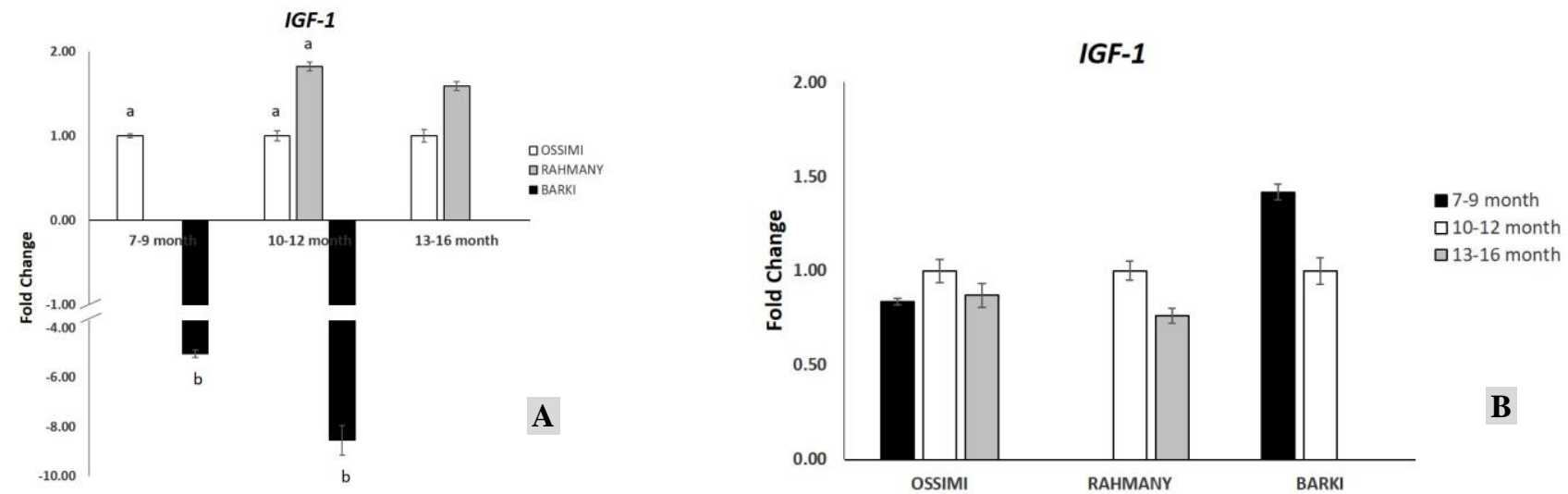

Figure 2. Expression differences in $I G F$-lbetween Egyptian breeds (A) or age categories among each breed (B). ${ }^{\mathrm{a}, \mathrm{b}, \mathrm{c}}$ Significant differences $(\mathrm{P}<0.05)$.
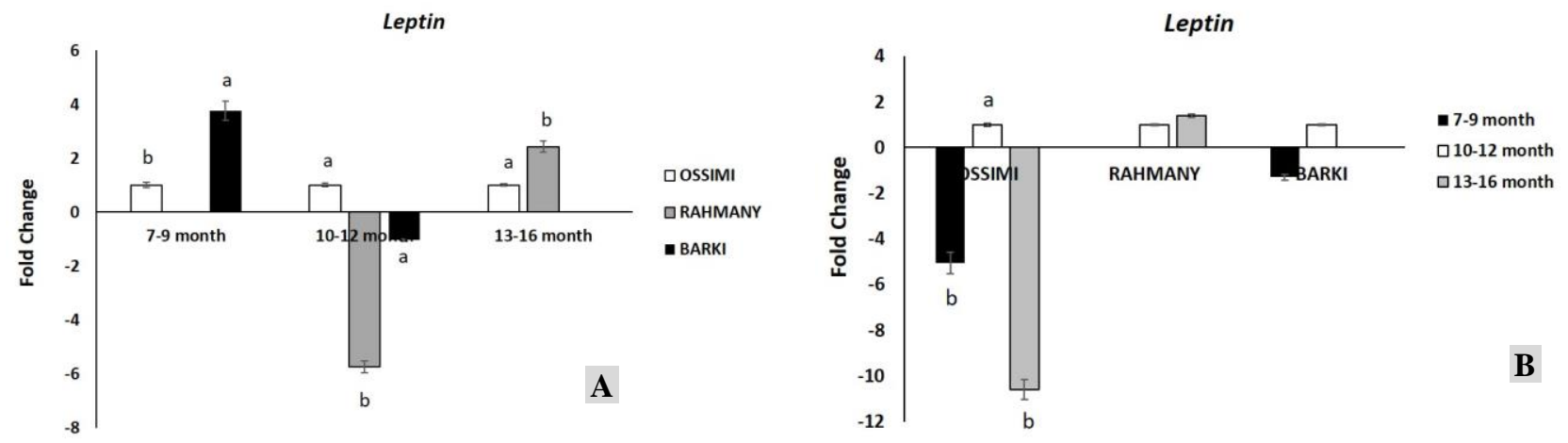

Figure 3. Differences in Leptin gene expression between Egyptian sheep breeds (A) or age categories among each breed (B). ${ }^{\mathrm{a}, \mathrm{b}, \mathrm{c}}$ Different letters indicate significant differences $(\mathrm{P}<0.05)$.

\section{DISCUSSION}

\section{Growth traits}

Measuring body weight is an accessible and necessary way to judge the value of lambs, the efficiency of raising and measure of economic profit. The identification of relationships between body weight and (breed, age, and body measurements) is very useful for selecting faster-growing animals.

Present results indicated that Ossimi sheep have the largest value of live body weight $(45.25 \pm 1.98 \mathrm{Kg})$ at the third age category, and there weren't any significant differences between Rahmani and Barki breeds. The results of this study are in harmony with those previously reported by Almahdy et al. (2000), Marai et al. (2009), Khalifa et al. (2013), Hassan (2017) and El-Malky et al. (2019). They mentioned that the average live body weights were ranged from (51-53 $\mathrm{kg}$ ) adult weight for the Ossimi and Rahmani breeds, and (44 kg) for the Barki breed. Another agreement obtained by Khalifa et al. (2013) they found a positive effect of advanced age for Rahmani males live body weight. Furthermore, Marai et al. (2009) and El-Malky et al. (2019) reported that breed had a significant $(\mathrm{P}<0.01)$ effect on live body weight as Ossimi breed showed heavier weight than Rahmani and Barki breed.Another point of view reported by El-Tarabany et al. (2017) they mentioned that there was no difference in live body weight between Ossimi and Rahmani breeds; however, Rahmani breed had a higher body weight compared to Ossimi breed. Body length differs according to many factors such as breed, gender, yield type, and age. According to Atta and El Khidir (2004), body length and height at wither were less variable measurement for predicting sheep live body weight.

The results of body length in current study are in the agreements with results obtained by Gad (2014) and Ibrahim (2015) who found that average body length of Ossimi and Rahmani breeds was $(71.5$ and $72.3 \mathrm{~cm})$ at 12 months, and the average of body length for Barki lambs at 9 months range from (71 to $75 \mathrm{~cm}$ ), while, Abd-Alla (2014) reported that the average of body length for Barki sheep was $(70.6 \mathrm{~cm})$ at 12 months.

Similar results obtained by Abdel-Moneim (2009) found that there weren't any significant differences in body length according to advanced ages and sheep breeds. Furthermore, Afolayan et al. (2006), Mahmud et al. (2014) and Abdullah et al. (2015) found a strong positive relationship between advanced age and all body measurements for Yankasa sheep, Nigerian, and Awassi sheep breeds respectively. Also, Shirzeyli et al. (2013) reported that there wasn't 
clear effect of sheep breed in sheep's body length and the average body length for four sheep breeds was $(46.28 \mathrm{~cm}$ for Mehrabani sheep, $52.50 \mathrm{~cm}$ for Shaal sheep, $50.96 \mathrm{~cm}$ for Macoei sheep and $54.64 \mathrm{~cm}$ for Zandi sheep).

The results are in the agreements with results obtained by Afolayanet al. (2006) and Mahmud et al. (2014) found a strong positive relationship between advanced age hip height for Yankasa sheep and Nigerian sheep breeds respectively. Same values reported by Musa et al. (2012) who found that the average height at the hip for Shugor sheep at 8 months of age was $72.98 \mathrm{~cm}$. In addition, Mahmud et al. (2014) reported that average body height for Nigerian sheep breeds was $57.09 \mathrm{~cm}$ for males and 46.56 for females from birth to less than 12 months and it was $59.07 \mathrm{~cm}$ and $59.76 \mathrm{~cm}$ for males and females respectively during the age from $13-24$ months.

The results of this study are in the harmony with results mentioned by Salako (2006) he found that there are a significant differences between sheep breed in average rump height for West African Dwarf and Yankasa sheep, the hip height was $59.20 \mathrm{~cm}$ for West African Dwarf and it was $72.57 \mathrm{~cm}$ for Yankasa sheep, which indicates that the Yankasa sheep is genetically bigger than West African Dwarf the sheep. Same values reported by El-Shahat et al. (2014) reported that average heart girth for Rahmani lambs were $(76.57 \mathrm{~cm})$ during the period for 6 to 12 months. Also, Depisonet al. (2017) indicated that the average heart girth for high land thin-tailed sheep males.

Other results by Shehata (2013) that recorded the average heart girth for Barki lambs at 12 months (99.58 cm). Another point of view noticed by Abd-Allah et al. (2018) who reported that the average of heart girth for males and females Assaf sheep was $105.40 \mathrm{~cm}$ it was $101 \mathrm{~cm}$ respectively from 6 to 18 months. Another view reported by AbdelMoneim (2009) and Shirzeyli et al. (2013) they found that there weren't any significant differences in heart girth with sheep breeds and advanced ages in Egyptian and Iranian sheep breeds respectively.

Using heart girth measurement to estimate the live body weight of the sheep's would help the breeders to calculate the amount of ration to feed and dose rate for medication. To increase meat yield from this type requires genetic improvement of its live body weight. Proper and accurate measurement of this morphometric trait is requisite for achieving this objective (Musa et al., 2012).

The results of present study indicated that the highest values of linear body measurements were observed in Ossimi breed and the recorded values of Barki and Rahmani breeds were very similar between both breeds. However, Rahmani breed had greeter values of body measurement comparing to Barki breed. The highest values of linear body measurements for Ossimi sheep may be referred to as that Ossimi breed had the heaviest body weight comparing to two others breed. Abdel-Mageed and Ghanem (2013), Shehata (2013), Agamyet al. (2015) and Ahmed et al. (2017) also found positive and significant $(\mathrm{p}<0.01)$ correlation coefficients between live body weight in 12 months reported similar results between body weight and body measurements.

\section{Blood metabolites}

The results of this study are similar to results that obtained by Nour El-Dinet al. (2009), El-Shahat et al. (2014) and Shaker (2014) who reported that plasma glucose level for Awassi sheep was (54 mg/ dl) at 164 days, for Rahmani lambs was (50-55) during the period from 6 to 12 months, and for Barki ewes ranged from (39.8 to $46.93 \mathrm{mg} / \mathrm{dl})$, respectively. While Cruz et al. (2017) reported that, plasma glucose levels for Dorper sheep were 85.4 (mg/ dl) from 15 to 30 days of age, $78.6(\mathrm{mg} / \mathrm{dl})$ from 45 to 61 days of age, $65.6(\mathrm{mg} / \mathrm{dl})$ from 74 to 90 days of age and $52.1(\mathrm{mg} / \mathrm{dl})$ from 105 to 121 days of age.

Anwaret al. (2012) reported a lower level of blood glucose compared to present results they reported that the mean values of plasma glucose for Egyptian sheep breeds were (45 for Barki, 44.15 for Rahmani and $48.01 \mathrm{mg} / \mathrm{dl}$ for cross breed Rahmani and Barki). Another point of view reported by Carloset al. (2015) they found that the values of glucose levels were not affected by the age in Morada Nova sheep during the period from 6 up to 15 months.

Many studies reported that there is an inverse relationship between lambs' age and blood glucose concentration, the higher concentration of blood glucose with early age may be due to stress of new lambs or may also be due to milk suckling as an important source of energy for newborns, as the consumption of nutrients through suckling directly interferes with the absorption and metabolism of carbohydrates (Braun et al., 2010; Abdel-Fattah et al., 2012; AbdelFattah et al., 2013; AL-Hadithy and Badawi 2015; Cruz et al., 2017; Rahman et al., 2018).

Similar results of breed effect obtained by El-Malkyet al. (2019) who found there wasn't a significant effect of breed on glucose levels. However, Barki breed had a higher concentration of blood glucose compared to Ossimi. Also, Stempaet al. (2016) showed that no significant differences were found between breeds (Dopper and Marino) on blood glucose. Same values of blood proteins were reviewed by Saleem et al. (2017), Rahman et al. (2018) and El-Malky et al. (2019) reported that average plasma total protein level for Saidi lambs, for Bangladesh sheep and for Ossimi and Barki was ranged from (6.07 to $7.59 \mathrm{~g} / \mathrm{dl}$ ) respectively. Also, Soliman (2015) and El-Bassiony (2016) mentioned that the average of blood total protein level $6.93 \mathrm{~g} / \mathrm{dl}$ for Ossimi males and it was $6.80 \pm 0.13 \mathrm{~g} / \mathrm{dl}$ in Barki ewes. Same trend reported by Carlos et al. (2015) found that the age of the sheep significantly affected inversely $(\mathrm{P}<0.05)$ the values of blood protein during the period from $6-12$ month $(7.84 \pm 0.32 \mathrm{~g} / \mathrm{dl})$ to $(5.61 \pm 0.15 \mathrm{~g} / \mathrm{dl})$ at the period more than 12 months of age in Morada Nova sheep. 
The reduction in blood total protein levels in this study with advanced age may be referred to as the reduction of animal growth rate after puberty. In addition to at earlier ages, the needs of blood protein are very important to help in transportation of calcium and phosphorus and other substances in the blood by attachment to the albumin. Same results for breed effect found by Farghaly et al. (2011) who documented that there were no significant differences due to breed and sex of sheep in total protein concentration; the Ossimi and Rahmani breeds showed similar mean of plasma total protein (7.00 vs. $6.97 \mathrm{gm} / \mathrm{dl})$ respectively and the average concentration for males and females was 6.95 and $6.99 \mathrm{gm} / \mathrm{dl}$ and also El-Malky et al. (2019) reported same trend for Ossimi and Barki.

Different results by Anwar et al. (2012) reported that Rahmani ewes showed a significant higher value of plasma total protein concentrations than both Barki and crossbred ewes, while there were no significant differences among all breeds in globulin concentration. The mean values of total protein concentrations were (7 for Barki, 7.38 for Rahmani $7.13 \mathrm{~g} / \mathrm{dl}$ for cross breed Rahmani and Barki). Same values measured by Cruz et al. (2012) reported that the mean values of plasma total lipids for Santa Inês male lambs at different ages were (1048, 1091, 1149 and $1191 \mathrm{mg} / \mathrm{dL})$ at (84, 168, 210 and 252 days), respectively. Lower levels of plasma total lipid reported by Anwaret al. (2012) reported that the mean values of plasma total lipids for Egyptian sheep breeds were 351.11 for Barki, 308.55 for Rahmani and $324.77 \mathrm{mg} / \mathrm{dl}$ for cross breed Rahmani and Barki. Meanwhile, Shaker (2014) found that the average serum total lipids in Barki ewes ranged from 254 to $303 \mathrm{mg} / \mathrm{dl}$ at 90 days. While, El-Bassiony (2016) mentioned that the averages of blood total lipids vary from $259.5 \pm 13.6$ to $322.6 \pm 13.1 \mathrm{mg} / \mathrm{dl}$ in Barki ewes.

An inverse opinion reported by Anwaret al. (2012) reported that there were significant differences among breed on total lipids concentrations. Moreover, they mentioned that Barki breeds have a great value of serum total lipids and cholesterol concentrations compared with those of Rahmani and crossbred ewes. Furthermore, Rahmani ewes had lower serum total lipid concentrations than crossbred ewes.

The results of present study are different with results which reported by El-Malkyet al. (2019) which they found that plasma total lipids were higher in Ossimi than Barki (2.95 and $2.59 \mathrm{~g} / \mathrm{l})$ respectively. This might refer to the lower size of fat tail in Barki sheep compared to Ossimi sheep.

\section{Gene expression analysis}

The ovine $\mathrm{GH}$ is a peptide encoded by a single gene about $1.8 \mathrm{~kb}$ long and it contains five exons and four introns in mammals (Hajihosseinlo et al., 2013). It has been mapped to chromosome 11 in Ovis aries. Growth hormone (GH) gene is a promising candidate gene for farm animals' genetic selection. It has many physiological functions, such as promoting muscle and bone growth, enhancing milk production for females and also semen quality for males and development of mammary gland, regulation of fat content, it plays an important role in postnatal longitudinal growth and development, tissue growth, lactation, reproduction, as well as protein, lipid, and carbohydrate metabolism in sheep (Kumariet al.,2013; Jia et al., 2014; Mazurowski et al., 2015; Farag et al., 2016; Abdelmoneim et al., 2017).

The analyses of gene expression demonstrated different levels of expression for $G H$ gene in all sheep breeds. The significant up-regulation of GH for Barki breed and Rahmani breed compared to the Ossimi breed may be related to Ossimi breed had a higher body weight compared to other breeds, therefore, Barki and Rahmani breeds need a greater concentration of growth hormone to achieve their maturity live weight.

The results indicated that the Barki breed had a significant down-regulation of IGF-1compared to the Ossimi breed in 7-9 months age category and Ossimi and Rahmani breeds in the 10-12 months age category. The result of this study is different than results reported by $\mathrm{Su}$ et al. (2014) who mentioned that IGF-I expression in Hu sheep increased from 2 days of birth and then continuously decreased until 3 months of age; thereafter, IGF-I expression gradually increased and reached the peak at 6 months of age, the expression of IGF-I in sheep that were 6 months of age was significant $(\mathrm{P}<0.01)$ and greater than at 1,2,3, and 4 months of age. The IGF1 gene plays an important purpose in the growth of multiple tissues, including mammalian muscle, somatic growth, and tissue repair (Nazari et al., 2016, Othman et al., 2016, Grochowska et al., 2017; Rotwein, 2017). IGF-1 gene is considered to be a candidate gene for predicting growth and meat quality traits in sheep genetic improvement schemes. It works to absorb glucose, decompose glycogen and increase the absorption of amino acids needed to synthesize protein and reduce protein degradation (Al Qasimi et al., 2019). Even though the IGF-I gene plays a role in the growth of an organism, it could also be directly or indirectly associated with other traits, i.e. carcass and meat quality traits (Grochowska et al., 2017).

Due to its important role in growth and reproduction traits, IGF-1 gene is considered as a candidate marker for these traits and its genetic polymorphism identification is of great interest in Egyptian small ruminant breeds (Othman et al., 2016). The leptin (LEP) gene was discovered in 1994 by Zhang et al. (1994) by positional cloning techniques. It is a promising candidate gene for voluble quantative traits in farm animals. Leptin gene has been mapped to the 5th chromosome in ovine consists of two introns and three exons that are involved in the synthesis of leptin hormone but only exons two and exons three are translated into protein (Javanmard et al., 2008). Leptin hormone, encoded by LEP gene, has significant importance in regulating various functions of growth, process and growth traits such as weaning 
weight, six-months body weight and nine-month body weight, etc. In addition to its functions, Saleem et al. (2018) stated this role in regulation of feed intake, metabolic process and meat quality traits in cattle, buffalo, goat and sheep.

The results of leptin gene expression in the current study showed that there were significant differences in the Ossimi breed between 10-12 months age category and two other age categories (Figure 3). This may be referred to Ossimi breed genetically have a greater amount of adipose tissues than Barki and Rahmani breed and also in present study Ossimi breed have the greater values of all physical body measurements.

The results of leptin gene expression in the current study (Figure 3) confirm the hormonal ones which obtained by Veena et al. (2018) they reported that there was a positive relationship between serum leptin concentration and advanced age in Bannur female sheep and the average serum leptin ranged from 1.36 to 2.35 (ng/mL). Also, Nieto et al. (2013) they reported that circulating concentrations of leptin increased from 1.3160 .02 to $1.7860 .01 \mathrm{ng} / \mathrm{ml}(\mathrm{P}<0.01)$ with advance age and leptin concentrations differed with ewe breed $(\mathrm{P}<0.05)$.

The opposite results mentioned by Zarkawi and Al-Daker (2018) they reported for Syrian Awassi ewe lambs that leptin concentrations did not among different age categories from puberty up to maturity and the overall average concentration was $(2.50 \pm 0.84 \mathrm{ng} / \mathrm{mL})$ from 6 to 12 months of age.

Up to current knowledge, this study is the first report discusses the gene expression analysis for G.H, IGF1, andleptin from circulating blood cells in Egyptian sheep during the selected period from 7 months of age to 16 months of age. However there was a previous study in cattle which measured the expression levels of IGF-1 gene in circulating blood cells by Lamas et al. (2018) and other studies in human measured the expression levels of G.H gene by Kelly et al. (2012) and leptin gene by Samara et al. (2008).

\section{CONCLUSION}

Based on present research, it can be concluded that Ossimi breed had the highest values of live body weight and linear body measurements compare to Barki and Rahmani breeds the recorded values of both breeds were very similar. Gene expression analysis showed that Ossimi and Rahmani breeds tend to have a pattern of higher expression levels of GH, IGF-1 and leptin genes. So, we suggest that measuring of physical body measurements, blood metabolites and GH, IGF1 and Leptin genes in early ages can be a good and accurate indicator of growth performance in Egyptian breed.

\section{DECLARATIONS}

\section{Author's contributions}

Gamal Ashour designed the plan of study and facilitate the experimental work, providing the experimental tools, revision of the research article, Ahmed Gad analyzed genes expression data, writing the results of gene expression analysis and revision of the research article, Ayat Alaa-El-Deen Fayed checked and approved the final form of manuscript, applied the particle part of the study and laboratory, writing of the research article and tabulation of the data, Neama Ashmawy helped in the design of the planned study, providing the experimental tools, revision of the research article, Ashraf El- Sayed helped in the designed the plan of study.

\section{Competing interests}

The authors have no competing interests, and we are with respect to this search and in agreement with each other. In addition, we have no conflict with authorship or article publication.

\section{Consent to publish}

All the authors approved and agreed to publish the manuscript

\section{REFERENCES}

Abbas SF, Abd Allah M, Allam FM and Aboul-Ella AA (2010). Growth performance of Rahmani and Chios lambs weaned at different ages. Australian Journal of Basic and Applied Sciences, 4(7): 1583-1589. Available at: http://www.ajbasweb.com/old/ajbas/2010/1583-1589.pdf

Abd-Alla MS (2014). A comparative study on body measurements and carcass characteristics in Egyptian sheep and goats. Asian Journal of Animal and Veterinary Advances, 9 (5): 292-301. DOI: http://dx.doi.org/10.3923/ajava.2014.292.301

Abd-Allah S, Shoukry MM, Mohamed MI, Abd- El Rahman HH and Abedo AA (2018). Some descriptive characteristics and linear body measurements of Assaf sheep reared in Southern Sinai in Egypt. Bioscience Research, 15(3):1679-1687. Available at: https://www.isisn.org/BR15(3)2018/1679-1687-15(3)2018\%20BR18-180.pdf

Abdel-Fattah MS, Abdel-Hamid AA, Ellamie MA, El-Sherief MM and Zedan MS (2012). Growth rate, some plasma biochemical and amino acid concentrations of Barki lambs fed ground date palm at Siwa Oasis, Egypt. American-Eurasian Journal of Agriculture \& Environmental Sciences, 12 (9): 1166-1175. DOI: http://10.5829/idosi.aejaes.2012.12.09.1895

Abdel-Fattah MS, Hashem ALS, Shaker YM, Ellamei MA and Amer HZ (2013). Effect of weaning age on productive performance and some plasma biochemical parameters of Barki lambs in Siwa oasis, Egypt. Global Veterinaria, 10 (2): 189-202. DOI: 10.5829/idosi.gv.2013.10.2.1104 
Abdel-Mageed I and Ghanem N (2013).Predicting body weight and longissimus muscle area using body measurements in subtropical goat kids. Egyptian Journal of Sheep and Goat Sciences, 8 (1): 95-100.

Abdel-Moneim AY (2009). Body and carcass characteristics of Ossimi, barki and Rahmani ram lambs raised under intensive production system. Egyptian Journal of Sheep and Goat Sciences, 4(2): 1-16. DOI: 10.21608/ejsgs.2009.27392

Abdelmoneim TS, Brooks PH, Afifi M and Swelum AA (2017). Sequencing of growth hormone gene for detection of polymorphisms and their relationship with body weight in Harri sheep. Indian Journal of Animal Research, 51 (2): 205-211. Available at: https://arccjournals.com/journal/indian-journal-of-animal-research/B-501

Abdullah BM, Al-Atiyat RM and Tabbaa MJ (2015).The Effects of Different Factors and Heterosis on Body Dimensions of Awassi, Chios and their Crossbred Lambs. Jordan Journal of Agricultural Sciences, 11(2): 423- 437. Available at: https://pdfs.semanticscholar.org/3bf0/277fd842f06474c77c66fdf6395f54131c6b.pdf?_ga=2.191793898.1104821477.15816817391528689128.1560991611

Afolayan RA, Adeyinka IA and Lakpini CAM (2006). The estimation of live weight from body measurements in Yankasa sheep. Czech Journal of Animal Science, 51(8): 343-348. https://www.agriculturejournals.cz/publicFiles/52310.pdf

Agamy R, Abdel-Moneim AY, Abd-Alla MS, Abdel-Mageed II and Ashmawi GM (2015). Using linear body measurements to predict body weight and carcass characteristics of three Egyptian fat-tailed sheep breeds. Asian Journal of Animal and Veterinary Advances, 10(7): 335-344. DOI: http://dx.doi.org/10.3923/ajava.2015.335.344

Ahmed SH, Omer SH and Elzaki RM (2017). Prediction of live body weight of Sudanese goat kids from body size measurements. International Journal of Livestock Research, 1:72-79. DOI:http://dx.doi.org/10.5455/ijlr.20170102113257

Al Qasimi RH, Hassan AF and Khudair BY (2019). Effect of IGF-1 and GH Genes polymorphism on weights and body measurements of Awassi lambs in different ages. Basrah Journal of Agriculture Science, 32(1): 39-46. DOI:https://doi.org/10.37077/25200860.2019.125

AL-Hadithy HA and Badawi NM (2015). Determination of Serum Proteins and Glucose Concentrations in Clinically Normal and Anemic Awassi Sheep. World`s Veterinary Journal, 5(1):1-6. DOI: http://dx.doi.org/10.5455/wvj.20150246

Almahdy H, Tess MW, El-Tawil E, Shehata E and Mansour H ( 2000).Evaluation of Egyptian sheep production systems: II. Breeding objectives for purebred and composite breeds. Journal of Animal Science, 78: 288-295. DOI: https://doi.org/10.2527/2000.782288x

Anwar MM, Nour El-Din ANM and Taha TA (2012). Changes in some hematological and serum biochemical parameters during the first week after lambing in six consecutive parities in some Egyptian sheep breeds. Egyptian Journal of Animal Production, 49(3):293-301. Available at: https://pdfs.semanticscholar.org/f53f/e3c1bb50fc06e8f23a3626e5aa7071e133fe.pdf?_ga=2.225355610.1104821477.15816817391528689128.1560991611

Atta M and El Khidir OA (2004). Use of heart girth, wither height and scapuloischial length for prediction of live weight of Nilotic sheep. Small Ruminant Research, 55: 233-237. DOI: https://doi.org/10.1016/j.smallrumres.2004.01.005

Barakat IAH, Salem LM, Daoud NM, Khalil WKB and Mahrous KF (2017). Genetic polymorphism of candidate genes for fecundity traits in Egyptian sheep breeds. Biomedical Research, 28 (2): 851-857. Available at: https://www.alliedacademies.org/articles/genetic-polymorphism-of-candidategenes-for-fecundity-traits-in-egyptian-sheep-breeds.pdf

Barzehkar R, Salehi A and Mahjoubi F (2009). Polymorphisms of the ovine leptin gene and its association with growth and carcass traits in three Iranian sheep breeds. Iranian Journal of Biotechnology, 7(4):241-246. Available http://www.ijbiotech.com/article_7083_21777b9ffc1bc05daa18b93ba9070b43.pdf

Beigh YA, Ganai AM, Ahmad HA, Mir DM, Bhat1 MA and Muzamil S (2018). Blood metabolic profile of lambs fed complete diet supplemented with exogenous fibrolytic enzymes cocktail. Journal of Animal Health and Production, 6(4): 96- 102. DOI: http://dx.doi.org/10.17582/journal.jahp/2018/6.4.96.102

Braun JP, Trumel, C and Bézille P (2010). Clinical biochemistry in sheep: a selected review. Small Ruminant Research, 92(1): 10-18. DOI:https://doi.org/10.1016/j.smallrumres.2010.04.002

Carlos MML, Leite JHGM, Chaves DF, Vale, AM, Façanha DAE, Melo MM and Soto-Blanco B (2015). Blood parameters in the Morada Nova sheep: influence of age, sex and body condition score. The Journal of Animal \& Plant Sciences, 25(4): 950-955. Available at: https://pdfs.semanticscholar.org/1dd7/7686b2cb5c83ecadaaa7f23430ff5faf0f57.pdf

Cruz RESda, Rocha FM, Sena CVB, Noleto PG, Guimarães EC, Galo JA and Mundim AV (2017). Effects of age and sex on blood biochemistry of Dorper lambs. Semina: Ciências Agrárias, Londrina, 38(5) 3085-3094. DOI: http://dx.doi.org/10.5433/1679-0359.2017v38n5p3085

Cruz SCL, Cruz RESda, Lima TR, Pérez JRO, Junqueira RS and CRUZ da BCC (2012). Correlation between lipid, cholesterol and fatty acid contents in the shoulder of castrated and non-castrated Santa Inês lambs. Revista Brasileira de Zootecnia, 41(7):1775-1783. DOI: http://dx.doi.org/10.1590/S1516-35982012000700030

Depison N, Anwar S, Jamsari A, Arnim A and Yurnalis S (2017).Association of growth hormone gene polymorphism with quantitative characteristics of thin-tailed sheep using PCR-RFLP in Jambi province. African Journal of Biotechnology, 16(20): 1159-1167. DOI:https://doi.org/10.5897/AJB2016.15783

Dixit SP, Singh G and Dhillon JS (2011). Genetic and environmental factors affecting fleece traits in Bharat Merino Sheep. Indian Journal of Animal Science, 81: 80-83.

Duncan DB (1995).Multiple range and multiple F-test. Biometrics, 11: 1-42.

Dunn C, and Ryan J (2015).The evolution of animal genomes. Current Opinion in Genetics \& Development, 35: 25-32. DOI:http://dx.doi.org/10.1016/j.gde.2015.08.006 0959-437/

El-Bassiony MF (2016).Impact of increasing twining rate in Barki ewes on milk yield, milk composition and lambs performance up to weaning. Australian Journal of Basic and Applied Sciences, 10(18):365- 376. Available at: http://www.ajbasweb.com/old/ajbas/2016/December/365376.pdf

EL-Hanafy AA and El-Saadani MA (2009). Fingerprinting Of Fecb Gene In Five Egyptian Sheep Breeds. Biotechnology in Animal Husbandry, 25 (34): 205-212. Available at: https://pdfs.semanticscholar.org/9dc7/8c92e25a378f47237c67a81e9da9e19f5de2.pdf

El-Malky OM, Mostafa TH, Ibrahim NH, Younis FE, Abd El-Salaam AM and Tag El-Din HA (2019). Comparison between productive and reproductive performance of Barki and Ossimi ewes under Egyptian conditions. Egyptian Journal of Sheep \& Goat Sciences, $14(1)$ : 61 - 82. DOI: http://dx.doi.org/10.1590/S1516-35982012000700030

El-Shahat KH, Khaled NF and El-Fa FI (2014).Influence of growth hormone on growth and onset of puberty of Rahmani ewe lamb. Asian Pacific Journal of Reproduction, 3(3): 224-230. DOI:https://doi.org/10.1016/S2305-0500(14)60030-0

Elshazly AG and Youngs CR (2019). Feasibility of utilizing advanced reproductive technologies for sheep breeding in Egypt. Part 1. Genetic and nutritional resources. Egyptian Journal of Sheep \& Goat Sciences, 14(1):39-52. DOI: https://dx.doi.org/10.21608/ejsgs.2019.33235

EL-Tarabany AA, Mostafa MMM and Mohamed AK (2017). Puberty and Fertility of Ewe Lambs Fed on By-products of Palm and Olive Oil. Arab Journal of Nuclear Sciences and Applications, 50(3): 137-150. Available at: http://www.esnsaeg.com/download/researchFiles/(14)\%20\%20\%20\%20\%20\%20121\%20-\%202016\%20\%20\%2014\%20puberty.pdf 
FAO (2017). Food and Agriculture Organization of the United Nations.FAOSTAT Online Statistical Service, Fao. Available at: http://Foastat.Fao.org.

Farag IM, Darwish AM, Darwish HR, AbdelAziz KB, Ramadan WA, Mohamed MI and Othman EO (2016). Polymorphism of growth hormone gene and its association with wool traits in Egyptian sheep breeds. African Journal of Biotechnology, 15(14):549-556. DOI: http://dx.doi.org/10.5897/AJB2015.14928

Farghaly HAM, El-Sayed AI and Nada TM (2011). Effect of some physiological parameters in female local sheep on some blood biochemical components and hormonal levels during pregnancy and lactation. Journal of Radiation Research and Applied Sciences, 4(4 A): $1219-1244$. Available at: https://inis.iaea.org/search/searchsinglerecord.aspx?recordsFor=SingleRecord\&RN=44083447

Gad SMA (2014). Estimation of genetic parameters for body measurements and their relationship with body weight in barki lambs. Journal of Animal and Poultry Production, 5 (8): 517 - 523. DOI: https://dx.doi.org/10.21608/jappmu.2014.70617

Galal S, Abdel-rasoul F, Anous MR and Shaat IM (2005). Onstation Characterization of Small Ruminant Breeds in Egypt. In: Characterization of Small Ruminant Breeds in West Asia and North Africa, 2: 141-193 Luis Iniguez (Ed.) ICARDA,Aleppo, Syria. Available at: https://cgspace.cgiar.org/handle/10568/66656

Gornal AG, Bardawill CJ and David MM (1949). Determination of serum proteins by means of the biuert reaction. TheJournal of Biological Chemistry, 177: 751- 766. Available at: https://www.jbc.org/content/177/2/751.short

Grochowska E, Borys B, Janiszewsk P, Knapik J and Mroczkowski S (2017). Effect of the IGF-I gene polymorphism on growth, body size, carcass and meat quality traits in Coloured Polish Merino sheep. Archives Animal Breeding, 60, 161-173. DOI: https://doi.org/10.5194/aab-60-161-2017

Hajihosseinlo A, Hashemi A, Razavi-Sheshdeh S and Pirany N (2013). Association of the polymorphism in the 5' flanking region of the ovine IGF-I gene with growth and development traits in Makui sheep of Iran. European Journal of Zoological Research, 2: 19-24. Available at: http://scholarsresearchlibrary.com/archive.html

Hassan TMM (2017). Effects of weaning age and some other factors on growth performance of Ossimi lambs. Egyptian Journal of Sheep \& Goat Sciences, 12(1): 29:38. DOI: https://dx.doi.org/10.21608/ejsgs.2017.26324

Ibrahim AHM (2015). Variability of Prion protein (prp) gene and its association with productive performance in Barki lambs. Journal of American Science, 11(2):89-96. ). Available at: http://www.jofamericanscience.org

Ibrahim NH (2014). Changes in haematological and physiological profile of Barki lambs and their dams fed salt tolerant plants silage during the postpartum period. Journal of Animal and Poultry Production, 5 (12): 793- 813.

Javanmard A, Mohammadabadi M, Zarrigabayi G, Gharahedaghi A, Nassiry M, Javadmansh A and Asadzadeh N (2008). Polymorphism within the intron region of the bovine leptin gene in Iranian Sarabi cattle (Iranian Bos taurus). Russian Journal of Genetics, 44: 495-497. Available at: https://link.springer.com/article/10.1134/S1022795408040169

Jia JL, Zhang LP, Wu JP, Ha ZJ and Li WW (2014). Study of the correlation between GH gene polymorphism and growth traits in sheep. Genetics and Molecular Research, 13 (3): 7190-7200. DOI: https://10.4238/2014.September.5.5.

Kelly BN, Haverstick DM, Vance ML, Thorner MO and Bruns DE (2012). Quantification of growth hormone mRNA in blood. Clinica Chimica Acta, 414: 206-210. DOI: https://doi.org/10.1016/j.cca.2012.09.011

Khalifa AI, Ahmed ME, Hafez YH, El-Zolaky OA, Bahera KM and Abido AA (2013). Age at puberty and fertility of Rahmani sheep fed on biological inoculated corn silage. Annals of Agricultural Science, 58(2): 163-172. DOI: https://doi.org/10.1016/j.aoas.2013.07.003

Kumari R, Kumar R, Meena AS, Jyotsana B, Prince LLL and Kumar S (2013). Genetic polymorphism of growth hormone gene in native sheep breeds of India. The Indian Journal of Small Ruminants, 20(2): 15-18. Available at: https://www.indianjournals.com/ijor.aspx?target=ijor:ijsr\&volume=20\&issue $=2 \&$ article $=003$

Lamas A, Regal P, Vazquez B, Miranda JM, Cepeda A and Franco CM (2018). Tracing recombinant bovine somatotropin a (use) through gene expression in blood, hair follicles, and milk somatic cells: a matrix comparison. Molecules, 23: 1-15. DOI: https://10.3390/molecules23071708.

Liu L (2007). Relative quantitative detection of HLA-G mRNA expression in patients with endometriosis by $2-\Delta \Delta c t$ method. China's Eugenic and Genetic Magazine,15: 25-26. Available at:http://en.cnki.com.cn/Article_en/CJFDTOTAL-ZYYA200709009.htm

Mahmud MA, Shaba P, Abdulsalam W, Yisa HY, Gana J, Ndagi S and Ndagimba R (2014). Live body weight estimation using cannon bone length and other body linear measurements in Nigerian breeds of sheep. Journal of Advanced Veterinary and Animal Research, 1(4): 169-176. DOI: http://dx.doi.org/10.5455/javar.2014.a29

Mahrous KF, Hassanane M, Shafey HI, Abdel Mordy M and Rushdi HE (2016).Association between single nucleotide polymorphism in ovine Calpain gene and growth performance in three Egyptian sheep breeds. Journal of Genetic Engineering and Biotechnology, 14: 233-240. DOI: https://doi.org/10.1016/j.jgeb.2016.09.003

Marai IFM, Daader AH and Bahgat LB(2009). Performance traits of purebred Ossimi and Rahmani lambs and their crosses with Finnsheep born under two accelerated mating systems. Archives Animal Breeding, 52 (5): 497-511. DOI: https://doi.org/10.5194/aab-52-497-2009

MazurowskiA, Frieske A, Kokoszyñski D, Mazurowski S, Bernacki Z and Wilkanowska A (2015). Examination of growth hormone (gh) gene polymorphism and its association with bodyweight and selected body Dimension in ducks. Folia Biologica (Kraków), 63 (1): 43-50. DOI https://doi.org/10.3409/fb63_1.43

Musa AM, Idam NZ and ELamin KM (2012). Regression analysis of linear body measurements on live weight in Sudanese Shugor sheep. Online Journal of Animal and Feed Research, 2(1): 27-29. Available at:http://www.ojafr.ir

Nath R, Das S, Sarma S and Devi M (2014). Comparison of blood profiles between healthy and Brucella affected cattle. Veterinary World, 7(9): 668670. DOI: https://10.14202/vetworld.2014.668-670.

Nazari F, Noshary A and Hemati B (2016). Association between insulin-like growth factor 1 polymorphism and early growth traits in Iranian Zandi sheep, found polymerase chain reaction restriction fragment length polymorphism (PCR-RFLP). Iranian Journal of Applied Animal Science, 6(3):665-669. Available at: http://ijas.iaurasht.ac.ir/article_524804_51812a854d24651167608b198058ee11.pdf

Nieto CAR, Ferguson MB, Macleay CA, Briege JR, Martin GB and Thompson AN (2013). Selection for superior growth advances the onset of puberty and increases reproductive performance in ewe lambs. Animal, 7(6): 990-997. DOI: https://10.1017/S1751731113000074.

Nour El-Din ANM, El-Zarkouny SZ, Ghobashy H, Abdel-Gawad EI andKesler DJ (2009). Growth, haematological and biochemical responses of growing lambs injected with growth hormone and supplemented with calcium soaps of fatty acids. South African Journal of Animal Science, 39(1):65-68. Available at: http://www.scielo.org.za/pdf/sajas/v39n5/v39n5a16.pdf

NRC (2002). Nutrient Requirements of Sheep. 6th Rev. Edn., National Academy of Sciences,National Research Council, Washington, DC., USA.

Othman EO, Abdel-Samad MF and Abo El-Maaty NA (2016).Evaluation of insulin-like growth factor-I gene polymorphism in Egyptian small ruminant breeds. African Journal of Biotechnology, 15(48): 2714-2719. DOI:http://dx.doi.org/10.5897/AJB2016.15727

Rahman MDK, Islam S, Ferdous J, Uddin MdH, Hossain MB, Hassan MM and Islam A (2018). Determination of hematological and serum biochemical reference values for indigenous sheep (Ovies aries) in Dhaka and Chittagong Districts of Bangladesh. Veterinary World, 11: 10891093. DOI: https://dx.doi.org/10.14202\%2Fvetworld.2018.1089-1093

Rotwein P (2017). Diversification of the insulin-like growth factor-1 gene in mammals. PLOS ONE, 12(12): 1-26. doi: 10.1371/journal.pone.0189642. 
Salako AE (2006). Application of morphological indices in the assessment of type and function in sheep. International Journal of Morphology, 24: 1318. DOI: http://dx.doi.org/10.4067/S0717-95022006000100003.

Saleem AH, Javed K, Babar ME, Hussain T, Ali A, Ahmad N, Farooq MZ and Dawood M (2018).Association of Leptin Gene Polymorphism with Growth Rate in Lohi Sheep. Pakistan Journal of Zoology, 50(3:, 1029-1033. DOI: http://dx.doi.org/10.17582/journal.pjz/2018.50.3.1029.1033

Saleem AM, Zanouny AI and Singer AM (2017). Growth performance, nutrients digestibility, and blood metabolites of lambs fed diets supplemented with probiotics during pre- and post-weaning period. Asian-Australas Journal of Animal Science, 30(4): 523-530. DOI: https://dx.doi.org/10.5713\%2Fajas.16.0691

Samara A, Marie B, Pfister M and Visvikis-Siest S (2008). Leptin expression in Peripheral Blood Mononuclear Cells (PBMCs) is related with blood pressure variability. Clinica Chimica Acta, 35: 47-50. DOI: https://10.1016/j.cca.2008.04.028.

SAS: Statistical analysis system institute (2008).SAS institute, Inc., Cary, MC, USA.

Shaker YM (2014). Live Body Weight Changes and Physiological Performance of Barki Sheep Fed Salt Tolerant Fodder Crops under the Arid Conditions of Southern Sinai, Egypt. Journal of American Science, 10 (2): 78-88. Available at:https://pdfs.semanticscholar.org/e5c4/882c5330f614aed54dab256162435b555f07.pdf?_ga=2.32940798.1104821477.15816817391528689128.1560991611

Shehata MF (2013). Prediction of live body weight and carcass traits by some live body measurements in Barki lambs. Egyptian Journal of Animal Production, 50(2): 69-75. Available at:https://www.esap1961.org/reserachgenerator/uploads/1399589135.pdf

Shirzeyli FH, Lavvaf A and Asadi A (2013).Estimation of body weight from body measurements in four breeds of Iranian sheep. Songklanakarin Journal of Science and Technology, 35 (5): 507-511. Available at:https://rdo.psu.ac.th/sjstweb/journal/35-5/35-5-2.pdf

Shojaei M, Abadi MM, Fozi MA, Dayani O, Khezri A and Akhondi M (2011). Association of growth trait and Leptin gene polymorphism in Kermani sheep. Journal of Cell and Molecular Research 2 (1), 67-73. DOI:https://doi.org/10.22067/jcmr.v2i2.3117

Singh SP, Dass G, Natesan R, Kushwah Y, Sharma N and Kumar A (2018). Endocrine and hematobiochemical profile of lambs raised in a semiarid region with different growth potentials during the post weaning period. Turkish Journal of Veterinary and Animal Sciences, 42: 120-129. DOI: https://10.3906/vet-1709-38

Soliman EB (2015). Dose-response of vitamin e and selenium injection on growth performance, physiological and immune responses of Ossimi lambs. Egyptian Journal of Sheep \& Goat Sciences, 10 (1): 27-40. DOI: https://dx.doi.org/10.21608/ejsgs.2015.26664

Stempa T, Muchenje V, Abrahams CAM and Bradley G (2016). Sex and breed affect plasma glucose, lactate, cortisol, meat quality but not muscle glycolytic potential of Dorper and Merino lambs. Animal Production Science, 1-8. DOI:https://doi.org/10.1071/AN16522

Su R, Sun RW, Li D, Wang QZ, Lv XY, Musa HH, Chen L, Zhang YFand Wu WZ (2014). Association between DLK1 and IGF-I gene expression and meat quality in sheep. Genetics and Molecular Research, 13: 10308-10319. DOI: https://doi.org/10.4238/2014.December.4.26

Trinder P (1969). Enzymatic determination of TAG. Annals of Clinical Biochemistry,6:24-27. Available at:https://www.scirp.org/(S(i43dyn45teexjx455qlt3d2q))/reference/ReferencesPapers.aspx?ReferenceID=130311

Veena MP, Swamy MN, Yathiraj S, Ramesh PT, Rao S, Shridhar NB, Kalmath GP and Shwetha HS (2018). Leptin, insulin and estradiol profile in Bannur female sheep. International Journal of Current Microbiology and Applied Sciences, 7(10): 507-511. DOI: https://doi.org/10.20546/ijcmas.2018.710.055

Vorachek WR, Bobe HG and Hall JA (2013). Reference Gene Selection for Quantitative PCR Studies in Sheep Neutrophils. International Journal of Molecular Sciences, 14: 1184- 1195. doi:10.3390/ijms140611484

Zarkawi M and Al-Daker MB (2018).Productive and reproductive parameters in high and low growing Syrian Awassi lambs. Acta Scientiarum. Animal Sciences, 40: 1-7. DOI: https://doi.org/10.4025/actascianimsci.v40i1.37983

Zhang Y, Proenca R, Maffei M, Barone M, Leopold L and Friedman JM (1994). Positional cloning of the mouse obese gene and its human homologue. Nature, 372: 425-432. DOI: https://doi.org/10.1038/372425a0

Zollner N and Kirsch K (1962). Über die quantitative bestimmung von lipoiden (mikromethode) mittels der vielen natürlichen lipoiden (allen bekannten plasmolipoiden) gemeinsamen sulfophosphovanillin - Reaktion. Zeits. fiir die gesam. Exp. Medizin, 135: 545-561. https://doi.org/10.1007/BF02045455 